\title{
Farklılıklarımız Zenginliğimiz mi? Bir İhtiyaç Analizi
}

“Dünyayı sadece kendi kültürel bakış açılarından anlamaya çalışan bireyler insanlık tecrübesinin önemli bir bölümünden mahrum kalmaktadırlar."

James A. Banks

Mehmet Fatih KAYAN, Abdurrahman KILIÇ¹

Atıf/C): KAYAN, Mehmet Fatih ve KILIÇ, Abdurahman. Farklılıklarımız Zenginliğimiz mi? Bir İhtiyaç Analizi, Artuklu İnsan ve Toplum Bilim Dergisi 2021/6 (1), 60-70.

Öz

$\mathrm{Bu}$ araştırmanın amacı, Sosyal Bilgiler dersi kapsamında Türkiye'deki kültürel farklılıkların öğrencilere tanıtılmasının planlandığı bir üniteye ait ihtiyaç analizinin yapılmasıdır. İhtiyaç analizlerinin temel amacı, bir öğretim programının hedef ve içerik boyutlarında bulunması gerekenleri ortaya koymaktır. Bu sayede eğitimciler, öğrencilerin gereksinimlerini daha iyi kavrar ve hangi konulara ne düzeyde yer verilmesi gerektiğine somut veriler ş̧ı̆̆ında karar verebilme olanağına sahip olurlar. Bu araştırmada, öğretmen ve öğrenci görüşlerinden yola çıkılarak yapılacak bir değerlendirme ile söz konusu değerlerin Sosyal Bilgiler öğretim programına ne yoğunlukta eklenmesi gerektiğinin belirlenmesi amaçlanmaktadır. Bu konuda işe koşulacak bir ihtiyaç analizi çalışmasının, toplumsal beklentilere cevap verecek daha işlevsel bir öğretim programının geliştirilebilmesine yol açacağı düşünülmektedir. Bu doğrultuda, Sosyal Bilgiler öğretmenleri ve ortaokul öğrencileri ile yapılan görüşmeler sonucunda öğrencilerin, ilgili konudaki farkındalıklarının, farklı1ıklara saygı duyma durumlarının ve empati becerilerinin istendik seviyede olmadığı ve geliştirilmeye muhtaç olduğu sonucuna ulaşıılmıştır. Bu bağlamda yapılması önerilen, kültürel farklılıkların öğrencilere tanıtılmasının amaçlandığı hedef ve kazanımlara öğretim programlarımızda daha yoğun bir şekilde yer vermektir. Sosyal bilgiler dersi, ilgili kazanımların öğrencilere aktarılması noktasında nitelikli bir araç olabileceği gibi sadece bahsi geçen kazanımların yer aldığı yeni bir ders ile bu amaca ulaşmaya çalışmanın daha doğru bir yol olduğu düşünülmektedir.

Anahtar Kelimeler: İhtiyaç Analizi; Kültürel Farklılıklar, Kültürel Farkındalık; Çok Kültürlülük

\section{Why Diversity Matters for Our Cultural Wealth? A Needs Assessment}

Citation/C): KAYAN, Mehmet Fatih ve KILIÇ Abdurahman. Why Diversity Matters for Our Cultural Wealth? A Needs Assessment, Artuklu İnsan ve Toplum Bilim Dergisi 2021/6 (1), 60-70.

\begin{abstract}
The aim of this study is to perform a needs assessment for a unit that is planned to introduce the cultural diversity in Turkey to middle school students within the scope of the Social Science course. The main purpose of needs assessments is to reveal what a curriculum must have in its goals and contents dimensions. In this way, educators comprehend the needs of the students better and have the opportunity to decide what subjects at which level should be included in the curriculum in the light of concrete data. In this study, it is aimed to determine the consistency of these values that are planned to be written into the Social Science curriculum with an evaluation based on the opinions of teachers and students. It is thought that a needs assessment study to be carried out on this subject will lead to the development of a more functional education program
\end{abstract}

${ }^{1}$ Dr. Öğr. Ü. Harran Üniversitesi, İlahiyat Fakültesi, Felsefe ve Din Bilimleri Bölümü e-mail: kayanfatih@yahoo.com Orcid: 0000-0002-4702-4080

Prof. Dr., Düzce Üniversitesi, Eğtim Fakültesi, abdurrahmankilic@duzce.edu.tr

Geliş/Received:15.01.2021 Kabul/Accepted:07.05.2021 


\section{F. KAYAN, A. KILIÇ}

that will meet social expectations. Hence, as a result of interviews with Social Science teachers and middle school students, it was concluded that students' cultural awareness, respect for differences, and empathy skills were not at the desired level and needed to be improved. Therefore, it was concluded that the cultural diversity in Turkey needs to be more recognized and known by students. Because of that, it is recommended to include more goals and earnings in our curricula, which are aimed at introducing cultural diversity to students. While the Social Science course can be a qualified tool for the transfer of related gains to students, it is thought that it is a better way to try to reach these goals with a whole new course that includes only the aforementioned gains.

Keywords: Needs Assessment; Cultural Differences; Cultural Awareness; Multiculturalism

\section{GİRiş}

Yaşadığımız çağın eğitimcileri geçmiş nesillerin hayalini bile kuramayacağ 1 kültürel çeşitlilik barındıran toplumlarda yaşamaktadırlar (Pewawardy, 2003). Bu doğrultuda dünyadaki her ülke, kendi sınırları içerisindeki çeşitli gruplar arasında etnik rekabet, düşmanlık ve çatışmayı en aza indirmeye çalı̧̧ır. Her ülke, etnik kökeni, ırkı, dili, dini inancı ne olursa olsun tüm vatandaşlarının ortak insanlık, ihtiyaçlar, umutlar ve korkuları paylaştığı ulusuna bağlı kalmasını sağlamak için çalışır (Hinton, 2011). Nitekim kültür, sosyal sınıf, din, dil ve etnik köken gibi farklılıklar kişiler arası etkileşimde toplumun temel özellikleridirler. Bireylerin bu farklılıklar konusunda erken yaşlarda eğitilmesinin, onların gelecekte küresel toplumun etkili birer üyesi olarak yetişmelerinde yararlı olacağı düşünülmektedir. Sözü edilen ayrıllklar, toplumların kutuplaşmasına, insanların birbirleriyle etkileşimlerinin kesilmesine ve toplumdan uzaklaşmalarına neden olabilmektedir (Gay, 1994).

Bu noktada eğitim sistemlerinden beklenen; farklı kültürlerin zenginlik olduğu, bir milleti zenginleştirdiği, yaşanan bireysel veya toplumsal sorunlarda çözüm yöntemlerini artırdığı bilincini öğrencilerine kazandırmasıdır (Aydın, 2013, akt. Marangoz, Aydın ve Adıgüzel, 2015). Bu doğrultuda insanlar, kendilerinden farklı kültürlere sahip olan insanları tanıdıkça insanları birbirinden ayrıştıran farklılıkların ne kadar az olduğunu fark edecek ve benzerliklerin farklılıklardan çok daha fazla olduğunu göreceklerdir. Bu sayede farklılıklara saygının önündeki en önemli engel olan ön yargılar kırılacaktır.

Nitekim bizler, araştırdıkça ve fark etme bilincini kazandıkça, çok zengin kültürel kaynaklarla beslendiğimizi ve yüzyllarca süren bir tarihi birlikteliğe sahip topluluklardan oluştuğumuzu görürüz. Gerek birey gerekse toplum olarak bu kültürel zenginliğimizin bilincinde ve onun taşıyıcısı olma durumundayız (Yılmaz, 2009). Böylelikle var oluştan getirdiğimiz ontolojik farklılıklar ile sonradan edinilen sosyal, kültürel, dini, vb. farklılıklarımızın, en evrensel anlamda 'var oluş zenginliğimiz' olduğu gerçeğini görebiliriz (Kılıç, 2006).

Farklılıklara saygı göstermek aynı zamanda demokrasinin de en temel ilkelerinden biridir. Nitekim toplumu oluşturan bireylerin karşılıklı olarak birbirine saygı duyması ve birbirini olduğu gibi kabul etmesi daha nitelikli bir toplumsal yaşantının temellerini oluşturmaktadır. Çatlak ve Yiğit (2017) farklılıklara saygıyı; insanları doğuştan sahip oldukları birincil karakteristik (ırk, etnik köken, yetenek, engellilik, cinsiyet ve cinsel yönelim) ve sonradan edindikleri ikincil karakteristik (eğitim durumu, ekonomik statü, dini inanç, yaşanılan coğrafya vb.) özelliklerine göre yargılamamak, herkesin kendi doğruları çerçevesinde yaşadığının farkında olmak, farklılıkları zenginlik olarak görebilmek ve toplum içerisinde yaşayan herkese sahip oldukları farklılıklarından dolayı sevgiyle bakıp hürmet gösterebilmek olarak tanımlamaktadırlar. 
Farklılıklar bir gerginlik ve ayrıştırma sebebi değil de, bir kültür zenginliği, karşılıklı yardımlaşma ve ilerleme aracı olarak algılandığı ve bir insanın, hangi dinden, milletten, renkten, coğrafyadan, dilden, düşünceden ve anlayıştan olursa olsun öncelikle insan olduğunun öneminin farkına varıldığı bir dünyada yaşamaya başladığımız gün 'Farklılıklarımız Zenginliğimizdir' söyleminin bir slogan olmaktan öteye giderek aslında bir yaşam felsefesi olduğunu görebileceğiz.

Farklı kültürlerin zenginlik olduğu, bir milleti zenginleştirdiği, yaşanan bireysel veya toplumsal sorunlarda çözüm yöntemlerini artırdığı (Aydın, 2013, akt. Marangoz, Aydın ve Adıgüzel, 2015) düşüncesi yaşadığımız çağda tüm dünyada yaygın bir şekilde kabul görmeye başlamıştır. $\mathrm{Bu}$ doğrultuda farklı kültürleri bünyesinde barındıran ülkeler, bu durumu toplumun birlik ve beraberliğine katkı sağlayan bir araç olarak görmekte ve avantaja çevirme gayreti içerisine girmektedirler. Birçok farklı kültürün bir arada yaşadığı ülkemizde bu konuda yeterince ilerleme kaydedilemediği gözlemlenmektedir. Bu bağlamda yapılması beklenen farklılıkların bir gerginlik ve ayrıştırma nedeni değil de bir kültür zenginliği, karşılıklı yardımlaşma ve bir ilerleme aracı olduğu algısının eğitim aracılığı ile küçük yaşlardan itibaren bireylere kazandırılmasıdır.

Kültürel farklılıkların bireye eğitim aracılığı ile tanıtılması, bu yönde yaşanması imkân dâhilinde olan problemlerin önüne geçilebilmesi bakımından büyük önem arz etmektedir. Banks (1994) farklı kültürlerin bir arada yaşadığı toplumlarda, etnik gruplar hakkında yanlış bilgilere sahip olma ve sahip olunan bilgilerin olumsuz yönde olması gibi durumlarla sıklıkla karşılaşıldığını belirtmektedir. Dolayısıyla farklı kültürlerin bireye tanıtılması görevini bizatihi devletin üstlenmesi büyük önem arz etmektedir. Böylelikle insanların, kendileri ile aynı toprakları paylaşan diğer kültürler hakkında yanlış bilgiye ve önyargıya sahip olabilme ihtimalleri en aza indirgenecektir.

Son yıllarda, etnik köken ve kültürel kimliklerin "yeniden keşfi" bir ülkedeki kültürlerin tanımlanması ve ülke bütünlüğünün sürdürülmesi tartışmalarını gündeme taşımıştır. Bu durum, bütünlük içinde etnik ve kültürel çeşitliliğin yönetimi ile başa çıkmak için, etnik ve kültürel azınlıkların toplumsal kaynaklara erişimiyle, topluma eşit katılımlarını teşvik eden politikalara ihtiyaç olduğu bilincinin oluşmasına neden olmuştur (Acar-Çiftçi ve Aydın, 2014). Bu bağlamda farklılıkların aslında birer zenginlik olduğu bilincinin öğrencilerde ne derece karşılık bulduğunu ve öğretim programlarımızda bu konuya ne düzeyde yer vermemiz gerektiğini anlayabilmenin en kesin yollarından biri bu konuda bir ihtiyaç analizine başvurmaktır. Öğretim programlarının geliştirilmesi sürecinin ilk basamağı olan fakat sıklıkla ihmal edilen ihtiyaç analizi daha nitelikli ve amaca hizmet eden bir programın meydana gelebilmesi bağlamında hayati bir değer taşımaktadır.

İhtiyaç analizi; öğrencilere ve öğretim programlarına ilişkin bilgi toplamak, eğitimsel ihtiyaçları ortaya koymak, neyin işe yarayıp neyin yaramadığını belirlemek için kullanılan sistematik bir yöntemdir (Walker, 2007). İhtiyaç analizinin temel amacı, bir öğretim programının içeriğinde bulunması gerekenleri ortaya koymaktır. $\mathrm{Bu}$ sayede eğitimciler öğrencilerin gereksinimlerini daha iyi kavrar ve hangi konulara ne düzeyde yer verilmesi gerektiğine somut veriler ışı̆̆ında karar verebilme olanağına sahip olurlar.

\section{Araştırmanın Amacı ve Önemi}

$\mathrm{Bu}$ araştırmanın genel amacı, Sosyal Bilgiler öğretim programı kapsamında 6. sınıf öğrencilerine yönelik olarak, ülkemiz toraklarında varlığını sürdüren kültürel farklılıkların tanıtılmasının planlandığı bir üniteye ait ihtiyaç analizinin yapılmasıdır. Bu genel amaç doğrultusunda, 6. sınıf öğrencilerinin ülkemizdeki farklı kültürleri ne derece tanıdığı, farklılıklara saygı duyma durumları ve farklı kültürlerden olan bireyler ile empati kurabilme becerilerinin istendik seviyede olup olmadığı sorgulanacaktır. 


\section{F. KAYAN, A. KILIÇ}

Sosyal Bilgiler öğretiminin temel amacı iyi insan ve iyi vatandaş yetiştirmektir. $\mathrm{Bu}$ nedenle Sosyal Bilgiler dersi değerler eğitiminde büyük bir öneme sahiptir (Kuş, Merey \& Karatekin, 2013). Bu doğrultuda öğrencilere farklılıkları tanıma ve onlara saygı duymanın yanı sıra farklı kültürlerden olan bireylerle empati kurma becerilerini kazandırma hedeflerini taşıyan bir ünitenin varlığının Sosyal Bilgiler dersinin temel amaçlarına hizmet edeceği düşünülmektedir. Bu bağlamda öncelikli olarak yapılması gereken öğrencilerin bahsi geçen değerlere ne düzeyde sahip olduklarının ölçülmesidir. Bu araştırmada, öğretmen ve öğrenci görüşlerinden yola çıkılarak yapılacak bir değerlendirme ile söz konusu değerlerin Sosyal Bilgiler öğretim programına ne yoğunlukta eklenmesi gerektiğinin belirlenmesi amaçlanmaktadır. Bu konuda işe koşulacak bir ihtiyaç analizi çalışmasının daha işlevsel bir öğretim programının geliştirilebilmesi amacına hizmet etmesi açısından önem arz ettiği düşünülmektedir.

\section{Yöntem}

\section{Araștırmanın Modeli}

Ortaokul öğrencilerinin; ülkemizde var olan farklılıkları tanıma, farklılıklara saygı duyma ve empati kurabilme becerilerini Sosyal Bilgiler öğretmenleri ve ortaokul öğrencilerinin görüşleri doğrultusunda belirlemeyi amaçlayan bu araştırmada, nitel araştırma desenlerinden durum çalışması kullanılmıştır. Nitel durum çalışmalarının en belirgin özelliği bir veya birkaç durumun derinlemesine araştırılmasıdır (Yıldırım \& Şimşek, 2006). Bu çalışmanın, ortaokul öğrencilerinin ülkemizde var olan farklılıkları tanıma, farklılıklara saygı duyma ve empati kurabilme becerilerini değerlendirmesi bakımından durum çalışması desenine uygun olduğu düşünülmektedir.

\section{Çalışma Grubu}

Araştırmanın çalışma grubunu, Türkiye'nin farklı bölgelerinde görev yapmakta olan 21 Sosyal Bilgiler öğretmeni ve ülkemizin farklı bölgelerinden insanların yoğun olarak ikamet ettiği Yalova ilinin farklı okullarında öğrenim görmekte olan 25 6. sınıf öğrencisi oluşturmaktadır. Çalışma grubuna dâhil edilen Sosyal Bilgiler öğretmenlerine ilişkin betimsel istatistikler Tablo 1 'de verilmiştir.

Tablo 1: Araştırmaya Katılan Sosyal Bilgiler Öğretmenlerine İlişkin Betimsel İstatistikler

\begin{tabular}{lc} 
Görev Yaptığı Bölge & Sayı (N) \\
Marmara & 6 \\
İç Anadolu & 2 \\
Ege & 1 \\
Güneydoğu Anadolu & 4 \\
Doğu Anadolu & 8 \\
\hline Toplam & $\mathbf{2 1}$ \\
\hline
\end{tabular}

Araştırmaya Türkiye'nin tüm coğrafi bölgelerinden öğretmenlerin katılımı amaçlanmış ve bu doğrultuda tüm bölgelerde görev yapan Sosyal Bilgiler öğretmenlerine görüşme formu ulaştırılmıştır. Görüşme formu ulaştırılan öğretmenlerden Marmara, İç Anadolu, Ege, Güneydoğu Anadolu ve Doğu Anadolu bölgelerinde görev yapan 21 öğretmenden geri dönüş sağlanmıştır.

Araştırmaya dâhil edilecek öğrencilerin seçiminde ise Yalova ili tercih edilmiştir. Farklı bölgelerde görev yapan öğretmenlerle yapılan istişareler sonucunda Yalova'nın çalışmanın kapsamına en uygun il olduğu sonucuna ulaşılmıştır. Farklı bölgelerden insanların bir arada 
yaşadığı bir şehir olan Yalova'nın aynı özelliğe sahip diğer illere göre yakın bir zaman diliminde göç alma oranının fazla olmasıyla İstanbul, İzmir vb. şehirlere göre kültürel farklılıkları daha belirgin olarak yansıttığı düşünülmektedir.

\section{Veri Toplama Araçları ve Verilerin Toplanması}

Araştırmada veri toplama aracı olarak araştırmacılar tarafindan geliştirilen Sosyal Bilgiler öğretmenleri ve ortaokul öğrencileri için hazırlanmış iki farklı yarı-yapılandırılmış görüşme formu kullanılmıştır. Görüşme formları üçer sorudan oluşmaktadır. Görüşme sorularında; ortaokul öğrencilerinin; ülkemizde var olan farklılıkları tanıma, farklılıklara saygı duyma ve empati kurabilme becerileri Sosyal Bilgiler öğretmenleri ve ortaokul öğrencilerinin görüşleri 1şı̆̆ında sorgulanmıştır. Hazırlanan taslak görüşme formları, uzman görüşü almak üzere Sosyal Bilgiler Öğretmenliği Anabilim dalında görev yapmakta olan üç öğretim üyesine gönderilmiş, uzmanların görüș ve önerileri doğrultusunda görüşme formlarındaki sorularda gerekli düzeltmeler yapılmıştır. Sosyal Bilgiler öğretmenleri için hazırlanmış olan soru formu, Türkiye'nin farklı bölgelerinde görev yapan öğretmenlere gönderilmiş ve 21 öğretmenden geri dönüş alınmıștır. Ortaokul öğrencileri için hazırlanan soru formu ise Yalova il merkezindeki 6. sınıf öğrencilerine öğretmenleri aracıllığı ile ulaştırılmıștır. Farklı bölgelerden ailelerin yoğun olarak bir arada yaşadığı ve bu yönüyle bir mozaik görüntüsü sergileyen Yalova, bu özelliğinden dolayı geçerli verilerin elde edilebileceği bir şehir olarak araştırmacılar tarafından özellikle tercih edilmiş̧ir.

\section{Verilerin Analizi}

Verilerin analizinde nitel veri analizi tekniklerinden betimsel analiz kullanılmıştır. Betimsel analizde amaç, elde edilen bulguların düzenlenmiş ve yorumlanmış bir biçimde okuyucuya sunulmasıdır. $\mathrm{Bu}$ analiz türünde katılımcıların görüşlerini çarpıcı bir şekilde yansıtmak amacıyla sık sık doğrudan alıntılara yer verilir. Betimsel analiz; betimsel analiz için tematik çerçeve oluşturma, temalara göre verilerin işlenmesi, bulguların tanımlanması ve yorumlanması olmak üzere dört aşamadan oluşmaktadır (Yıldırım ve Şimşek, 2006). Bu araştırmada verilerin analizinde şu süreçler izlenmiştir. Görüşme sorularından hareketle temalar belirlenmiş, belirlenen temalara göre veriler betimlenmiş ve yorumlanmıştır. Ayrıca, görüşme verilerini açık ve net bir şekilde yansıtabilmek ve öğretmen ve öğrenci görüşlerini çarpıcı bir biçimde ortaya koyabilmek amacıyla bulgular doğrudan alıntılarla desteklenmiştir.

\section{Bulgular}

Sosyal Bilgiler öğretmenleri ve ortaokul 6. sınıf öğrencileri ile yapılan görüşmelerden elde edilen veriler, "farkındalık, farklılıklara saygı ve empati" temaları altında sınıflandırılmıştır. Aşağıda, belirlenen temalara ilişkin bulgu ve yorumlara yer verilmiştir.

\section{Farkındalık}

\section{Öğretmen Görüşleri}

Bu temaya ilişkin Sosyal Bilgiler öğretmenlerine "Sizce öğrencileriniz ülkemizdeki farklı kültürleri ne ölçüde tanımaktadırlar?" sorusu yöneltilmiştir. Görüşmelerde öğretmenlerin tamamına yakını öğrencilerinin kültürel farklılıkları tanımadıklarını belirtmiş, bir kısım öğretmenler ise kültürel farklılıkları tanımamalarının öğrencilerde farklı kültürlere yönelik bir önyargı oluşturduğunu dile getirmiştir. Öğretmenler, öğrencilerin farklı kültürleri tanımamalarını, genel olarak yaşadıkları bölgelerden dışarı çıkmamaları, öğretim programlarının bu konudaki yetersizliği ve öğrencilerde kitap okuma alışkanlığının olmaması gibi nedenlere bağlamışlardır. Görüşme yapılan öğretmenlerin küçük bir kısmı, öğrencilerin kısmen dahi olsa ülkemizdeki farklı kültürleri tanıdığını belirtmiştir. Öğretmenlerden sadece biri, öğrencilerin ülkemiz bağlamında kültürel farkındalığa sahip olduğunu belirtmiş bu durumu da görev yaptığı okulun kozmopolit 


\section{F. KAYAN, A. KILIÇ}

yapısına bağlamıştır. Öğretmenlerin, ortaokul öğrencilerinin farklı kültürleri tanımalarına yönelik genel bakışını yansıtan bazı örnek görüşlere aşağıda yer verilmiştir.

“Öğrencilerimizin çoğunluğu kendi kültürel çevreleriyle sinırlı bir düşünceye sahip, farklı kültürlere karşı bilgi düzeylerinin yetersiz olduğınu düşünüyorum. Kültürel farkllllkları bilme düzeylerinin genelde yaşanan mahalle veya yaşadıkları şehirle sinırl oldukların gözlemliyorum."(Öğrt4)

"Öğrencilerimizin, ülkemizdeki farklı kültürleri tanımaları konusunda eksikleri vardır. Farklı kültürleri pek tanımazlar. Bunu bazen konuştuğumuz konuşmalardan rahatllkla çıkarabiliyoruz. Bunun temel sebebi de farklı bölgelere pek çımamalarıdır." (Öğrt5)

"Bu konuda ciddi eksikliklerinin olduğunu düşünüyorum. Eğitim sistemimiz ve müfredatımızın da bu konuda yeterli olmadı̆̆ını düşünüyorum. İnsanın tanımadı̆̆ına düşman olması düsturundan yola çlkarak bu bilgisizliğin ayrışmaya sebep olduğunu düşünüyorum." (Ö̈̆rt8)

"Farklı kültürlere yabancı ve önyargllllar. Kendi şehirlerinin dışına çıkmayan bireyler olarak farkl yerlerde hayatın kendi hayatlarından çok farklı olduğunu düşünüyor ve farklllkkları olumsuzluk olarak görüyorlar." (Öğrt12)

"Öğrencilerimiz sadece yakın çevresinde var olan kültüre aşina olup diğer kültürler hakkinda klsmen bilgi sahibidir." (Öğrt16).

"Genel olarak farkında oldukların gözlemledim. Birazda görev yaptı̆̆ım okulun kozmopolit yapısı bu duruma etken olmuş olabilir." (Öğrt18)

\section{Öğrenci Görüşleri}

$\mathrm{Bu}$ temaya ilişkin ortaokul öğrencilerine "Ülkemizdeki farklı kültürleri ne ölçüde tanıdığınızı düşünüyorsunuz?” sorusu yöneltilmiştir. Öğrencilerin bu soruya verdikleri cevaplardan ülkemizdeki farklı kültürleri yeterince tanımadıkları sonucuna ulaşılmıştır. Öğrenciler, farklı kültürleri yeterli düzeyde tanımamalarını; yeterince gezip görmeme, fazla kitap okumama ve farklı kültürlerin kendilerine tanıtılmaması gibi nedenlere bağlamışlardır. Ülkemizdeki farklı kültürleri tanıdığını öne süren öğrenciler ise genel olarak kültürel farklılıkların doğu kültürü ve batı kültürü ile sınırlandığını düşünmektedirler. Bu konuda öğrencilerden gelen cevaplardan birkaçına aşağıda yer verilmiştir. $(\ddot{O} \breve{g} r 5)$

"Ben yeterince tanımlyorum çünkü her yeri gezip görecek kadar büyümedim daha."

“Çok gezemiyoruz, az ölçüde kitap okuyoruz. Bu yüzden çok tanımıyoruz.” (Öğr22)

"Ben batı kültürünü çok fazla tanıyıp yorumlamama rağmen doğu kültürünü tanımlayamıyorum bile." (Ö̈̆r23)

Bu temaya ilişkin öğretmen ve öğrenci görüşlerinden elde edilen bulgulara göre öğrenciler ülkemizde var olan farklı kültürlere ilişkin yeterli düzeyde bilgi sahibi değildirler. Bu durum bilhassa öğretmenler tarafından bir eksiklik olarak nitelendirilmektedir. Nitekim görüşüne başvurulan öğretmenlerin birçoğu farklılıklardan haberdar olmamalarının öğrencilerde bir takım olumsuz tutumlar gelişmesine yol açtığını gözlemlediklerini belirtmektedirler. Öğretmenler, bu durumun en temel nedenlerinden biri olarak öğretim programlarının bu konudaki yetersizliğini görmektedirler. 


\section{Farklılıklara saygı}

\section{Öğretmen Görüşleri}

$\mathrm{Bu}$ temaya ilişkin öğretmenlere "Öğrencilerinizin farklı kültürlere yeterli düzeyde saygl duyduğunu düşünüyor musunuz? Lütfen görüşlerinizi gerekçelendirerek açıklayınız” sorusu yöneltilmiştir. $\mathrm{Bu}$ konuda öğretmenlerin farklı görüşlere sahip oldukları belirlenmiştir. Öğretmenlerin bir kısmı, öğrencilerin farklı kültürlerden insanlara karşı yeterli düzeyde saygı duyduğunu belirtirken, bir kısım öğretmenler ise öğrencilerin farklı kültürlerden bireyleri yeterince kabullenmediğini ve saygı duymadığını öne sürmüştür. Öğrencilerinin farklı kültürlerden olan bireylere saygı duymadığını düşünen öğretmenler, bu durumu öğrencilerin farklılıkları tanımamalarına ve medyanın olumsuz etkisine bağlamaktadırlar. Öğretmenlerden bazıları bu konuyu şu an ülkemizde yaşayan Suriyeli göçmenler üzerinden değerlendirmiş ve bu insanlara hak ettikleri saygının gösterilmediğini belirtmiştir. Görüşme yapılan öğretmenlerin bir kısmının ise öğrencilerinin farklılıklara sayg1 duyup/duymadı̆̆ı konusunda yeterli düzeyde bilgiye sahip olmadıkları gözlemlenmiştir. Bu duruma ilişkin görüş belirten öğretmenlerin görüşlerinden ön plana çıkanlar aşağıda sunulmuştur. (Öğrt1)

“Çoğu ögrrencim farklı kültürlere sahip öğrencilere karşı saygı ve sabır içinde olmuştur."

"Başka kültürleri benimsemekte zorlansalar bile saygısı bir yaklaşım tarafimca gözlenmemiştir.” (Ö̆ğrt19)

"Çalıştığım okulda farklı kültürlerden birçok öğrenci var. Genel olarak saygı duyduklarını ve beraber uyumla yaşadıklarını söyleyebilirim. Fakat zaman zaman hemşericilik adıyla guruplaşmaların ve çatışmaların yaşandiğına da şahit olmuşumdur. ” (Öğrt8)

"Farklı kültürleri tam olarak tanımadıkları için saygı da duymuyorlar. Onlar için kendilerinden farklı ise kendilerine dost değildir. ” (Öğrt14)

"Farklı kültürlere bakış açısının genelde medya etkisi altında olduğunu gözlemliyorum. Bazı kültürlere karşı saygılı olmakla beraber bazı kültürlere karşı saygısız tutum içinde olduklarını düşünüyorum." (Ö̈̆rt2)

"Çocuklar televizyondan gördükleri kadarlyla farklı kültürleri tanımaktadırlar. Bu yüzden yeteri kadar saygı göstermemektedirler.” (Öğrt11)

“Bu konuda zaman zaman eksiklikler olduğunu gözlemleyebiliyorum. Suriyelilere karşı önyargıları ve benimseyemeyişleri olabiliyor.” (Öğrt4)

\section{Öğrenci Görüsşleri}

Bu temaya ilişkin ortaokul öğrencilerine "Farklı kültürlere saygı denince ne anlıyorsunuz? Kendinizi bu konuda ne kadar yeterli görüyorsunuz?” soruları yöneltilmiştir. Görüşmelerden elde edilen verilere göre öğrencilerin yarıya yakınının farklı kültürlere saygı denince ne anlıyorsunuz sorusuna herhangi bir cevap vermediği ortaya çıkmıştır. Bu soruyu cevaplandıran öğrencilerin, farklı kültürlere saygı ifadesinden başka insanların yaşam tarzına hoşgörü ile yaklaşma anlamı çıkardıkları görülmektedir. Kendinizi bu konuda ne kadar yeterli görüyorsunuz? sorusuna ise farklı cevaplar verilmiştir. Öğrencilerin bir kısmı kendini bu konuda yeterli görmekte bir kısım öğrenciler ise farklı kültürlere saygı duymanın gerekli olmadığını savunmaktadırlar. Bu temaya ilişkin öğrenci yorumlarından çarpıcı birkaç ifadeye aşağıda yer verilmiştir.

"Sadece kendi kültürüme saygl duymuyorum. Benim kültürüm kadar farklı kültürlerde önemlidir. Kendimi çok iyi ve yeterli buluyorum.” (Öğr16) 
"Herkesin inancına kültürüne saygı duyduğumu düşünüyorum." (Öğrl)

"Diğer kültürler çok fazla umurumda değill." (Öğr5)

$\mathrm{Bu}$ temaya ilişkin elde edilen bulgular, her ne kadar öğrencilerin birçoğunun farkl11ıklara saygılı olduğunu ortaya koysa da göz ardı edilemeyecek oranda bir çoğunluğun diğer kültürlere yeterince saygı duymadığı hatta saygı duymanın gerekliliğinin dâhi farkında olmadığı sonucunu ortaya koymaktadır. Bu durum bir önceki temada ortaya çıkan farklılıkları yeterince tanımama bu yüzden de onlara ön yargı ile yaklaşma sonucuyla ilişkilendirilebilir. Bunun yanında bir grup öğretmen bahsi geçen sorunu, öğrencilerin bu konuda medyadan olumsuz yönde etkilenmesiyle açıklamaktadırlar.

\section{Empati}

\section{Öğretmen Görüşleri}

$\mathrm{Bu}$ temaya ilişkin öğretmenlere "Öğrencilerinizin, farkl kültürlerden olan bireylere karşı empati kurabilme becerilerine ilişskin görüşleriniz nelerdir?" sorusu yöneltilmiştir. Öğretmenler, genel olarak öğrencilerinin farklı kültürlerden olan bireylere karşı empati kuramadığını düşünmektedirler. $\mathrm{Bu}$ durum, öğretmenler tarafından öğrencilerin henüz empati kurabilecek olgunluğa ulaşmadığı ve farklılıkları yeterince tanımadığı şeklinde açıklanmaktadır. Öğrencilerinin farklı kültürlerden olan bireylere dönük empati becerisine sahip olduğunu düşünen sınırlı sayıdaki öğretmenler ise bu durumu farklı kültürlerle bir arada yaşamalarına bağlamaktadır. Öğretmenlerin bu konuya ilişkin belirttiği bazı görüşler şöyledir.

“Bu becerilerinin çok gelişmediğine şahit oluyorum. Öğrencilerimin zaman zaman bir takım durumlara tepki göstermelerine karşı, 'siz de bu durumda olabilirdiniz' uyarımın yeteri kadar etkili olmadlğını gözlemliyorum. " (Öğrt4)

"Empati becerilerinin gelişstiğini düşünmüyorum. Uyumlu bir şekilde yaşamalarını birbirlerine alı̧̧a olarak yorumluyorum. Çünkü spesifik olaylarda empati becerisiyle çözülebilecek problemlerde çözüme yönelik empati becerisinin işletilmesine pek rastlayamiyoruz. Daha çok kendisinin haklılı̆̆ını ispatlamayla karşılaşlyoruz." (Öğrt8)

"Farklı kültürleri daha iyi tanıdıklarında ve etkileşim halinde olduklarında empati kurabilme becerilerinin gelişeceği kanısindayım." (Öğrt11)

"Ara ara taklştıkları oluyor. Ama genel olarak bizdeki ögrenciler kaynaştıkları ve aynı ortamda büyüdükleri için empati düzeyleri yüksek.” (Öğrt18)

\section{Öğrenci Görüşleri}

$\mathrm{Bu}$ temaya ilişkin ortaokul öğrencilerine "Farklı kültürlerden bireyler ile empati kurabildiğinizi düsünüyor musunuz? sorusu yöneltilmiştir. Bu soruya, öğrencilerin önemli bir çoğunluğu olumlu cevaplar vermiştir. Fakat öğrencilerin bu konuya ilişkin açıklamaları detaylı olarak incelendiğinde birçoğunun empati kavramını tam olarak içselleştirmemiş olduğu sonucuna ulaşılmıştır. Nitekim öğrencilerin bu soruya ilişkin 'evet' ya da 'kurabilirim' ile başlayan görüşleri, sonrasında yaptıkları açıklamalar ile çelişmektedir. Öğrencilerin küçük bir kısmı ise farklı kültürlerden bireyler ile empati kuramadığını dile getirmiştir. Bu konuya ilişkin öğrenci görüşlerinden birkaçına aşağıda yer verilmiştir.

"Evet, benim farklı kültürlerde arkadaşlarım var ve onlarla iyi zaman geçiriyorum. Çünkü birbirimizde olmayan kültürleri ögreniyoruz.” (Öğr14)

“Evet, çünkü onların kültürüne saygll olmalıyız.”(Öğr18)

“Evet, çünkü hepimiz insanız.” (Öğr3) 
“Empati kurabildiğimi düşünmüyorum. Nedenini bile bilmiyorum.” (Ö̈̆r21)

$\mathrm{Bu}$ temaya ilişkin elde edilen bulgular, öğrencilerin farkındalık ve farklılıklara sayg1 temalarında olduğu gibi bu konuda da istendik seviyede olmadıklarını göstermektedir. Buna rağmen bahsi geçen sonuca sadece öğretmen ve öğrenci görüşleri aracılığıyla, herhangi bir gözlem veya ölçek uygulaması olmaksızın ulaşıldığından elde edilen bulguların gerçeği ne derece yansıttığı tam olarak kestirilememektedir.

\section{SONUÇLAR ve ÖNERÍLER}

Ortaokul öğrencilerinin, ülkemizdeki farklı kültürleri tanıma, farklılıklara saygı duyma ve farklı kültürlerden bireyler ile empati kurabilme becerilerinin incelendiği bu çalışma 21 Sosyal Bilgiler öğretmeni ve 25 ortaokul öğrencisi ile yürütülmüştür. Çalışma grubuna dâhil edilen öğrenciler farklı kültürlerin bir arada yaşadığı Yalova il merkezinden seçilmiş, öğretmenlerin ise farklı coğrafi bölgelerde görev yapmasına özen gösterilmiştir.

Sosyal Bilgiler öğretmenleri ve ortaokul öğrencilerinin görüşlerinden yola çıkılarak ulaşılan sonuçlara göre öğrenciler ülkemizde ki farklı kültürleri yeterli ölçüde tanımamaktadırlar. Onlarca farklı kültürün yaşamını idame ettirdiği ülkemizde, öğrencilerin bu konudaki yetersizliği öğretmen ve öğrenciler tarafından; öğretim programlarının bu konuyu sınırlı bir şekilde ele alması, öğrencilerin yaşadıkları bölgenin dışına çıkarak farklı kültürlerden bireylerle tanışma imkânı bulamaması ve istendik düzeyde kitap okuma alışkanlıklarına sahip olmamaları ile gerekçelendirilmiştir. Görüşüne başvurulan öğretmenlerin bir kısmı, öğrencilerin farklı kültürleri tanımamalarının onlarda diğer kültürlere yönelik bir önyargı meydana getirdiğini öne sürmüşlerdir. Bir grup öğrenci farklı kültürleri yeterli düzeyde tanıdığını dile getirse de araştırmadan elde edilen veriler, öğrencilerin önemli bir çoğunluğunun bu konuda sınırlı oranda bilgiye sahip olduğunu göstermektedir. Nitekim bu konuda kendini yeterli gören öğrencilerin bile genel olarak kültürel farklılıkları doğu kültürü-batı kültürü gibi yüzeysel bağlamda ele aldıkları görülmektedir.

Çalışma grubunu oluşturan öğretmen ve öğrenci görüşleri incelendiğinde, farklılıklara sayg1 bağlamında kötümser bir manzara ile karşılaşılmamasına rağmen bu durumun Anadolu insanının genel olarak saygıya verdiği değerden mi yoksa bilinçli bir şekilde farklı kültürlere saygı duyulduğundan mı kaynaklandığı anlaşılamamıştır. Nitekim görüşüne başvurulan öğretmenlerden biri, öğrencilerinin farklı kültürlerden bireylere yönelik olumsuz bir tavrını görmediğini fakat bu durumun özel olarak farklılıklara saygı duyulması gerektiği bilinciyle ortaya çıkmadığını fark ettiğini belirtmektedir. Öğretmenlerin bir kısmı, öğrencilerin farklı kültürleri yeterince tanımadığını ve bu durumun onlarda kendi kültürlerinden olmayan bireylere yönelik hoşgörüden yoksun bir yaklaşım tarzına sebep olduğunu dile getirmektedirler. Bir grup öğrencinin, farklı kültürlerden olan bireylere saygı duyulmasını gereksiz bir tutum olarak değerlendirmesi de farklılıkları yeterince tanımamalarının ortaya çıkardığı bir durum olarak yorumlanmaktadır. Öğrencilerinin farklı kültürlerden bireylere hoşgörüden yoksun bir şekilde yaklaştığını öne süren bazı öğretmenler ise medyanın bu yöndeki olumsuz etkisine atıfta bulunmaktadırlar.

Sosyal Bilgiler öğretmenleri ve ortaokul öğrencilerinin empati temasına yönelik görüşleri incelendiğinde, öğrencilerin farklı kültürlerden bireylere yönelik olarak yeterli düzeyde empati kuramadığı sonucuna ulaşılmıştır. Bu durum öğretmenler tarafından, öğrencilerin henüz empati kurabilecek olgunluğa ulaşmamış olması şeklinde açıklanmıştır. Bu konuda öğrencilerden alınan cevaplar öğretmen görüşleriyle örtüşmektedir. Nitekim empati temasına ilişkin olarak elde edilen öğrenci görüşleri incelendiğinde birçok öğrencinin empati kavramına yabancı olduğu görülmektedir. 


\section{F. KAYAN, A. KILIÇ}

Ülkemizde yaşayan kültürler, "ebru” sanatında olduğu gibi, birbiriyle kaynaşmış ve "kitre" ile birbirine bağlanmıştır. Ancak her renk ve desen de "ebru"da olduğu gibi kendi özgün yapısını korumaktadır. Farklı etnik yapıların, dinlerin ve kültürlerin, Türkiye Cumhuriyeti vatandaşı olma potasında birleştirilerek, karşılıklı hoşgörü ve empati geliştirme üzerine temellendirilmesinin anlamlı olacağı düşünülmektedir (Crrık, 2008). Nitekim yaşadığımız çağda kültürel farklılıklar, engelleyici bir neden olarak değil sinerji oluşturan bir yapı olarak düşünülmektedir (Ehtiyar, 2003).

Ülkemiz topraklarında varlığını idame ettiren, Rum, Ermeni, Kürt, Arap, Süryani gibi topluluklar çok kültürlü yapıya sahip bir devlet olduğumuzun en belirgin göstergesidir. Farklı kültürlerin bir arada yaşaması, ülkemize önemli bir zenginlik kazandırmaktadır. Nitekim gelişen ve değişen dünyada çeşitlilik ve farkl1lıklar artık bütünlüğü ve birlikteliği bozmaya yönelik tehdit edici unsurlar olarak değil aksine bir varlık ve zenginlik olarak nitelendirilmektedir (Gencer, 2011). Ülkemizin bahsi geçen zenginlikten istendik seviyede istifade edebilmesi için öncelikli olarak bu farklılıkların herkes tarafından yeterli düzeyde bilinmesi gerekmektedir. Böylesi önemli bir görevin topluma, diğer bir deyişle aileye, akrabalara, komşulara sevk edilmesi, işin bir nevi şansa bırakılması anlamına gelecektir ki kültürel farklılıkların tanınması ve onların bir zenginlik aracı olarak görülmesi şansa bırakılamayacak kadar değerli bir konudur. Bu bağlamda genelde eğitim sistemimizden, özelde de öğretim programlarından beklenen, öğrencilerin ilgili konuda herhangi bir önyargı ya da dezanformasyona maruz kalmadan önce, onlara okullar ve öğretmenler aracılığıyla kültürel zenginliklerin tanıtılması ve bu doğrultuda sahip olmaları beklenen iletişim becerilerinin kazandırılmasıdır.

Öğrenciler, öğrenme ortamlarına; kültürel geçmiş, cinsiyet, inanç, ideolojik görüş, rrk gibi çok geniş bir yelpazede yer alan değişkenleri getirmektedirler (Başbay, 2014). Bu değişkenlerin öğrenciler tarafından bir ayrıştırma sebebi değil de zenginlik ve ilerleme aracı olarak algılanabilmesi ancak kültürel farklılıkların tüm öğrencilere tanıtılması ile mümkün olabilecektir. Nitekim sahip olduğumuz bu zenginliklerin tanıtılması için en güzel yer okullar, en nitelikli araç ise eğitimdir.

Bu çalışmadan elde edilen sonuçlar evrensel bir bakış açısı ile ele alındığında, ülkemizde yaşamını sürdüren farklı kültürlerin vatandaşlarımıza tanıtılmasının daha nitelikli bir toplum olabilme bağlamında olumlu etkileri olacağı sonucuna ulaşılmıștır. Bu doğrultuda yapılması önerilen, kültürel farklılıkların öğrencilere tanıtılmasının amaçlandığı hedef ve kazanımlara öğretim programlarımızda daha yoğun bir şekilde yer vermektir. Sosyal bilgiler dersi, ilgili kazanımların öğrencilere aktarılması noktasında nitelikli bir araç olabileceği gibi sadece bahsi geçen kazanımların yer aldığı yeni bir ders ile bu amaca ulaşmaya çalışmanın daha doğru bir yol olduğu düşünülmektedir. Nitekim ülkemizde birçok farklı ırk, kültür ve dini inançlardan bireyler bir arada yaşamaktadırlar. Bahsi geçen farklılıklara sahip olan insanların birbirini tanıması ve birbirine hoşgörü ile yaklaşması daha yüksek bir refah seviyesi ve mutlu bir toplumsal yaşantı için bir önkoşul olarak görülmektedir. Bu da ancak eğitim aracılığıla gerçekleşebilecek bir hedeftir.

Öğretim programlarımızda bu konuya hak ettiği değer verildiği takdirde, farklılıkları zenginlik olarak görebilen, herkesin yaşam tarzına, düşüncesine, inancına saygı gösterebilen, empati ve duyarlılık gücü olan, farklı bakış açılarını bir öğrenme aracı olarak gören, farklı kültürlerin insanlık tecrübesinden istifade edebilen bireylerden oluşan bir toplum yakın zaman içerisinde bizleri bekliyor olacaktır. 


\section{KAYNAKÇA}

Acar-Çiftçi, Y. \& Aydın, H. (2014). Türkiye'de Çokkültürlü Eğitimin Gerekliliği Üzerine Bir Çalışma. SDÜ Fen Edebiyat Fakültesi Sosyal Bilimler Dergisi(33), 197-218.

Banks, J. A. (1994). An Introduction to Multicultural Education. Needham Heights, MA: Allynand Bacon Inc.

Başbay, A. (2014). Çokkültürlü Eğitim Kapsamındaki Derslerinin İncelenmesi: Georgia State Üniversitesi Örneği. Kuram ve Uygulamada Eğitim Bilimleri, 14(2), 585-608.

Cırık, İ. (2008). Çok Kültürlü Eğitim ve Yansımaları. Hacettepe Üniversitesi Eğitim Fakültesi Dergisi, 34, 27-40.

Çatlak, İ. H., \& Yiğit, E. Ö. (2017). Sosyal Bilgiler Öğretmen Adaylarına Empati Becerisi ve Farklılıklara Saygılı Olma Değerinin Kazandırılmasında Storyline Yönteminin Etkisi. Abant İzzet Baysal Üniversitesi Eğitim Fakültesi Dergisi, 17(4), 1794-1819.

Ehtiyar, R. (2003). Kültürel Sinerji: Uluslararası İşletmelere Yönelik Kavramsal Bir İrdeleme. Akdeniz Üniversitesi İktisadi ve İdari Bilimler Fakültesi Dergisi, 3(5), 66-78.

Gay, G. (1994). A Synthesis of Scholarship in Multicultural Education. Naperville, IL: North Central Regional Education Laboratory.

Gencer, Z. T. (2011). Çok Kültürlü Toplumlarda İletişim: Divriği Örneği. Gümüşhane Üniversitesi İletişim Fakültesi Elektronik Dergisi, 1(1), 186-205.

Hinton, S. (2011). Ethnic Diversity, National Unity and Multicultural Education in China. US-China Education Review B, 1(5), 726-739.

Kılıç, S. (2006). Medeniyetler Çokluğu Var Oluş Zenginliğimizdir. Atatürk Üniversitesi Ilahiyat Fakültesi Dergisi, 26, 1-9.

Kuş, Z., Merey, Z., \& Karatekin, K. (2013). İlköğretim 4. ve 5. Sınıf Sosyal Bilgiler Ders Kitaplarında Yer Alan Değerler. Değerler Eğitimi Dergisi, 11(25), 183-214.

Marangoz, G., Aydın, H,. \& Adıgüzel, T. (2015). Öğretmenlerin Çok Kültürlü Eğitime Karşı Algısı. International Periodical For The Languages, Literature and History of Turkish or Turkic, 10(7), 709-720.

Pewewardy, C. (2003). 100 Defensive Tactics and Attributions: Dodging the Dialog on Cultural Diversity. Multicultural Education, 11(1), 23-28.

Walker, K. (2007). Needs Assessment. Research Brief. Education Partnerships, Inc.

Yıldırım, A. \& Şimşek, H. (2006). Sosyal Bilimlerde Nitel Araştırma Yöntemleri. Ankara: Seçkin Yayıncılık.

Yılmaz, İ. (2009). Kültürel Zenginlik Bakımından Mardin. Dinbilimleri Akademik Araştırma Dergisi, 9(4), 51-70. 